\title{
Kinetics of aerobic decomposition in the leaching phase of allochthonous plant detritus
}

\author{
Cinética da decomposição aeróbia na fase de lixiviação dos detritos vegetais alóctones
}

André Luiz dos Santos Fonseca ${ }^{1}$, Irineu Bianchini Jr. ${ }^{2,3}$, Cristiane Marques Monteiro Pimenta ${ }^{4}$, Norberto Mangiavacchi ${ }^{4}$ and Cássio Botelho Pereira Soares ${ }^{5}$

${ }^{1}$ Instituto Federal de Educação, Ciência e Tecnologia do Rio de Janeiro, Rua Carlos Wenceslau, 343, CEP 21715-000, Rio de Janeiro, RJ, Brazil e-mail: andre.fonseca@ifrj.edu.br

${ }^{2}$ Programa de Pós-graduação em Ecologia e Recursos Naturais, Universidade Federal de São Carlos - UFSCar, Rodovia Washington Luiz, Km 235, CP 676, CEP 13565-905, São Carlos, SP, Brazil

${ }^{3}$ Departamento de Hidrobiologia, Universidade Federal de São Carlos, Rodovia Washington Luiz, Km 235, CP 676, CEP 13565-905, São Carlos, SP, Brazil e-mail: irineu@ufscar.br

${ }^{4}$ Grupo de Ensaios e Simulaçôes Ambientais em Reservatórios, Universidade do Estado do Rio de Janeiro - UERJ, Rua Fonseca Teles, 121, CEP 20940-903, Rio de Janeiro, RJ, Brazil e-mail: cmmpimenta@yahoo.com.br; norberto.mangiavacchi@gmail.com

${ }^{5}$ Furnas Centrais Elétricas, Rua Real Grandeza, 219, CEP 22281-900, Rio de Janeiro, RJ, Brazil e-mail: cassiobp@furnas.com.br

\begin{abstract}
Aims: This study aimed to evaluate, through an experiment with short sampling intervals, (1) the effects of detritus quality on dissolved oxygen (DO) consumption, on dissolved inorganic carbon (DIC) formation and on the stoichiometric ratio between the $\mathrm{DO}$ consumed and mineralized carbon $(\mathrm{O} / \mathrm{C}$ ratio) during leaching of plant detritus in the early decomposition; (2) the temporal variation of the variables mentioned above according to changes in the quality of each detritus over time. Methods: The detritus of leaves, branches and litter (3 g) previously dried were incubated in decomposition chambers containing $1 \mathrm{~L}$ of inoculum. The chambers were maintained at $24 \pm 2{ }^{\circ} \mathrm{C}$ in aerobic condition. The DO concentrations dissolved organic carbon (DOC) and DIC were evaluated. The consumption of DO was adjusted to a first-order kinetic model. The hourly rates of DO consumption, DIC production and $\mathrm{O} / \mathrm{C}$ ratios were determined. Results: The DO consumption $\left(2.62 \mathrm{mg} \cdot \mathrm{g}^{-1}\right)$ and DIC production $\left(1.20 \mathrm{mg} \cdot \mathrm{g}^{-1}\right)$ were higher in leaves decomposition, and smaller in litter (1.50 and $0.42 \mathrm{mg} . \mathrm{g}^{-1}$, respectively). Inversely, the $\mathrm{O} / \mathrm{C}$ ratio was higher in the decomposition of litter (3.56). The rates of DO consumption $\left(0.50 \mathrm{mg} \cdot \mathrm{g}^{-1} \cdot \mathrm{h}^{-1}\right)$ and DIC production $\left(0.41 \mathrm{mg} \cdot \mathrm{g}^{-1} \cdot \mathrm{h}^{-1}\right)$ were greatest in the early decomposition of leaves. Conclusions: Short sampling intervals are key to understanding the dynamics of decomposition in the leaching phase. Higher consumption of DO in leaves decomposition indicated a higher content of labile compounds in this detritus. The highest $\mathrm{O} / \mathrm{C}$ ratios in the litter decomposition can be attributed to its higher content of refractory substances. Variations in DO consumption rates and in $\mathrm{O} / \mathrm{C}$ ratios over time suggest that the leachate is heterogeneous, comprising labile and refractory fractions, analogous to the detritus as a whole. In terms of water quality alterations, leaves constituted the most critical resource and the litter presented less pronounced effects.
\end{abstract}

Keywords: oxygen consumption, mineralization, dissolved organic carbon, anoxia, reservoir.

Resumo: Objetivos: Este estudo teve como objetivo avaliar, através de um experimento com intervalos amostrais curtos, (1) os efeitos da qualidade dos detritos no consumo de oxigênio dissolvido (OD), sobre a formação de carbono inorgânico dissolvido (CID) e na relaçâo estequiométrica entre o OD consumido e o carbono mineralizado $(\mathrm{O} / \mathrm{C}$ ratio $)$ durante a lixiviaçáo de detritos de plantas no início da decomposição; (2) a variação temporal das variáveis mencionadas acima de acordo com as alteraçóes na qualidade de cada detrito ao longo do tempo. Métodos: Os detritos de folhas, galhos e serapilheira (3 g) previamente secos foram incubados em câmaras de mineralização contendo $1 \mathrm{~L}$ de inóculo. As câmaras foram mantidas a $24 \pm 2{ }^{\circ} \mathrm{C}$, em condição aeróbia. As concentrações 
de OD, carbono orgânico dissolvido (COD) e CID foram avaliadas. O consumo de OD foi ajustado a um modelo cinético de primeira ordem. As taxas horárias de consumo de $\mathrm{OD}$ e produção de CID e as razóes $\mathrm{O} / \mathrm{C}$ foram determinadas. Resultados: $\mathrm{O}$ consumo de OD $\left(2,62 \mathrm{mg} \cdot \mathrm{g}^{-1}\right)$ e a produção de CID $\left(1,20 \mathrm{mg} \cdot \mathrm{g}^{-1}\right)$ foram maiores na decomposição das folhas, e menores na serapilheira $\left(1,50 \mathrm{mg} \cdot \mathrm{g}^{-1}\right.$ e $0,42 \mathrm{mg} \cdot \mathrm{g}^{-1}$, respectivamente). Inversamente, a razão $\mathrm{O} / \mathrm{C}$ foi maior na decomposição da serapilheira $(3,56)$. As taxas de consumo de OD $\left(0,50 \mathrm{mg} \cdot \mathrm{g}^{-1} \cdot \mathrm{h}^{-1}\right)$ e de produçáo de CID $\left(0,41 \mathrm{mg} \cdot \mathrm{g}^{-1} \cdot \mathrm{h}^{-1}\right)$ foram maiores no início da decomposição do detrito de folhas. Conclusóes: Intervalos amostrais curtos são fundamentais para a compreensão da dinâmica de decomposição na fase de lixiviação. $\mathrm{O}$ maior consumo de $\mathrm{OD}$ na decomposiçáo das folhas indicou maior teor de compostos lábeis nesse detrito. As maiores razóes $\mathrm{O} / \mathrm{C}$ na decomposição da serapilheira podem ser atribuídas ao seu maior teor de substâncias refratárias. As variaçóes nas taxas de consumo de $\mathrm{OD}$ e nas razóes $\mathrm{O} / \mathrm{C}$ sugerem que o lixiviado é heterogêneo, compreendendo substâncias lábeis e refratárias, assim como o detrito como um todo. Em termos de alteraçôes da qualidade da água, as folhas constituíram o recurso mais crítico e a serapilheira apresentou os menores efeitos.

Palavras-chave: consumo de oxigênio, mineralização, carbono orgânico dissolvido, anoxia, reservatório.

\section{Introduction}

Reservoir construction to satisfy human needs can damage or eliminate ecosystem services (Tundisi 1999; Fitzhugh and Richter, 2004). Within many reservoirs considerable periods of anoxia and eutrophication occur immediately after dam closure as a result of the decomposition of newly submerged vegetation (Paiva, 1988; Cunha-Santino et al., 2013). The establishment of anoxia depends on the amount of terrestrial plant biomass and hydraulic residence time (Figueiredo and Bianchini Jr., 2008; Cunha-Santino et al., 2013). The change from a lotic (streams) to lentic (reservoirs) ecosystem implies changes in the proportion and amount of detritus input in the aquatic environment. In streams, the leaves are the main source $(>70 \%)$ of detritus and the input occurs continuously or with seasonal variations (França et al., 2009; Tank et al., 2010). On the other hand, in the formation of reservoirs the proportion of detritus input changes because the plant is completely flooded and the large amount plant biomass from the reservoir basin (Paiva, 1988; Alves et al., 2010) suddenly enters the environment. Therefore, the variety of vegetal structures and their classes of compounds (refractory and labile fractions) have to be considered to obtain a precise description of decomposition processes in reservoirs (Ferreira et al., 2012; Pettit et al., 2012).

The better descriptions of detritus decomposition are those that consider the detritus as a heterogeneous source (Bianchini Jr. and Cunha-Santino, 2008). In this context, the decomposition can be described as a biphasic process with a fast initial mass loss attributed to leaching, followed by a more gradual mass loss due to microbial decomposition (Cunha-
Santino and Bianchini Jr., 2006). During the leaching phase, the intense mineralization of labile compounds (half-time 0.9 day) generates conditions for dissolved oxygen depletion and eutrophication (Petts, 1984; Bianchini Jr. and Cunha-Santino, 2005). Deforestation could be used in order to minimize or neutralize the environmental alterations caused by changes in the water quality owing to decomposition of plant detritus, despite the financial costs and operational risks (Paiva, 1988).

Implicit in the oxygen consumption is the relation between the amounts of oxygen consumed per carbon oxidized, named as stoichiometric ratio (O/C ratio) (Brezonik, 1994). At first, the low values observed in the stoichiometric ratio occur by the decomposition of labile organic carbon and subsequently the ratio evolves to higher values, as the refractory detritus remains, requiring greater quantity of oxygen per carbon oxidized (Peret and Bianchini Jr., 2004; Bianchini Jr. et al., 2006). Therefore, studies on the $\mathrm{O} / \mathrm{C}$ stoichiometry confirm that the high oxygen demand observed early in the decomposition is due to oxidation of the large amount of labile organic carbon from terrestrial plant biomass drowned, culminating in anoxic conditions in newly formed reservoirs (Cunha-Santino and Bianchini Jr., 2002).

Despite the importance of leaching due to the capacity to cause oxygen depletion and eutrophication, many studies use a simple model or quite large sampling intervals, neglecting this rapid phase of the decomposition process (CunhaSantino and Bianchini Jr., 2006). In this context, we conducted an experiment with measurements at 
short sampling intervals in laboratory microcosms to detail the temporal variation of DOC release, $\mathrm{O}_{2}$ consumption, $\mathrm{DIC}$ formation and $\mathrm{O} / \mathrm{C}$ ratios in the early hours of leaching of terrestrial plant detritus (leaves, branches and litter). Detritus with a higher initial amount of DOC were considered of higher quality. We aimed to test the following hypotheses:

(1) Detritus quality positively affects decomposition

$\left(\mathrm{O}_{2}\right.$ consumption, DIC formation and $\mathrm{O} / \mathrm{C}$ ratio); (2) $\mathrm{O}_{2}$ consumption, the formation of DIC and $\mathrm{O} / \mathrm{C}$ ratio present temporal variation according to changes in detritus quality along the decomposition.

\section{Material and Methods}

\subsection{Design of oxygen consumption experiments}

The sampling of green plants (mixed leaf and mixed branches) and moist soil used in the experiments were made according to Fonseca et al. (2013). In the laboratory, we previously prepared the inoculum in which the detritus samples were incubated. The inoculum consisted of incubation of $5 \mathrm{~g}$ of soil in $1 \mathrm{~L}$ of deionized water over a period of $6 \mathrm{~h}$. Subsequently, the water was filtered through nylon mesh to remove the coarse debris. To establish the aerobic condition, the inoculum was aerated through air bubbling until the oxygen saturation. The purpose of the inoculum was supplying nutrients and soil microorganisms for initiating the decomposition process. To evaluate the oxygen consumption during the breakdown of resources (leaf, branches and litter), we established 12 experimental chambers (polyethylene bottles, volume of $1 \mathrm{~L}$ ) containing $1 \mathrm{~L}$ of the prepared inoculum, by gentling introducing the water into the chambers. The treatments established were 3 chambers containing $3 \mathrm{~g}$ of mixed leaf detritus, 3 chambers containing $3 \mathrm{~g}$ of mixed branches detritus, 3 chambers containing $3 \mathrm{~g}$ of litter and 3 chambers without detritus (control treatment). The DO concentration and temperature (oximeter YSI, model 55-12); the electrical conductivity (conductivity meter Quimis, model Q 795P) and $\mathrm{pH}$ (potentiometer Quimis, model Q 400BC) were determined. The three sensors and a hose connected to a sampling syringe were kept immersed in the bottles throughout the experiment to avoid opening the caps in each measurement. To keep the sensors and the hose immersed during the whole time, the caps of the bottles were prepared with four holes, and after the passage of the sensors and the hose through the holes, the cap was sealed with silicone glue to prevent loss of gases. Since the sensors and the hose were kept immersed in bottles, determinations were made completely at one bottle at a time. During the first 7 hours the measurements were taken every 30 minutes. From that time, the determinations were made every 1 hour, until the oxygen concentration reaches values around $0.30 \mathrm{mg} \mathrm{O} \cdot \mathrm{L}^{-1}$.

To determine the concentration of DOC and DIC, $5 \mathrm{~mL}$ aliquots from each bottle were removed through the hose and syringe and immediately filtered (pore size membrane $=0.45 \mu \mathrm{m}$, Millex ${ }^{\circledR}$ Durapore PVDF membrane). Subsequently, concentrations of total carbon and DIC were determined on a carbon analyzer (Shimadzu - VCPN-TOC). Concentrations of DOC were determined by subtracting the values of total carbon and DIC. Carbon measurements were taken every hour for each bottle.

\subsection{Data analysis}

Using a nonlinear method (LevenbergMarquardt iterative algorithm; Press et al., 2007), the evolution of accumulated oxygen consumption over time was adjusted to the first-order kinetic model described in Equation 1, where the deoxygenation coefficient $\left(\mathrm{k}_{\mathrm{d}}\right)$ and the total amount of consumed oxygen were estimated $\left(\mathrm{OC}_{\max }\right)$.

$\mathrm{OC}=\mathrm{OC}_{\operatorname{MAX}}\left(1-\mathrm{e}^{-\mathrm{k}_{\mathrm{d}} \mathrm{t}}\right)$

where $\mathrm{OC}$ is accumulated consumed oxygen $\left(\mathrm{mg} \mathrm{g}^{-1}\right.$ detritus DW); $\mathrm{OC}_{\mathrm{MAX}}$ is total amount of consumed oxygen ( $\mathrm{mg} \mathrm{g}^{-1}$ detritus DW); $\mathrm{k}_{\mathrm{d}}$ is deoxygenation rate constant, $\left(\right.$ hour $\left.^{-1}\right)$; $\mathrm{t}$ is time (hour).

The temporal variations of the $\mathrm{O} / \mathrm{C}$ values were calculated through the ratios between the hourly rates of consumed oxygen $(\mathrm{dOC} / \mathrm{dt})$ and of the oxidized organic carbon (dDIC/dt) (Cunha-Santino and Bianchini Jr., 2002). Most of the leaching losses consist of carbon (Ibrahima et al. 1995). A study of leaching ( 4 hours of extraction) of litter elements with 41 species of tropical woody plants showed that, although the carbon had the lowest soluble fraction (3\%), on a litter mass basis more C $(14.7 \mathrm{mg} / \mathrm{g}$ litter) was extracted than any of the other elements investigated ( $, \mathrm{P}, \mathrm{K}, \mathrm{Ca}, \mathrm{Mg}, \mathrm{Na}$ ), which had $<1 \mathrm{mg} / \mathrm{g}$ litter (Schreeg et al., 2013). Therefore, to calculate the $\mathrm{O} / \mathrm{C}$ stoichiometric ratio, we assume that oxygen was consumed primordially by the decomposition of $\mathrm{C}$.

The differences of DOC release, DIC formation, $\mathrm{DO}$ consumption, $\mathrm{O} / \mathrm{C}$ ratio, conductivity, and the rates of DOC release, DIC formation and DO consumption (dependent variables) from aerobic decomposition of leaves, branches and litter 
(categorical variables) of terrestrial vegetation per sample time (continuous variable) were compared using an analysis of covariance (ANCOVA; significance level of 0.05 ).

\section{Results}

The detritus breakdown resulted in a significantly different DOC release between the resources, with leaves showing the larger quantities and litter the lowest (Figure 1a; Table 1). DOC release rates also presented significantly higher values in leaves than in branches and litter (Figure 1b; Table 1). The highest rate of DOC release was observed in the first hour of leaves decomposition and then the rates decreased until the end (Figure 1b). Branches also presented the highest rate in the first hour of decomposition, but in litter decomposition it was observed only after $6 \mathrm{~h}$ of decomposition (Figure 1b).

DIC formation followed the same pattern observed in the release of DOC. The decomposition of leaves showed the highest amount of DIC production, followed by the branches and litter (Figure 1c, Table 1). DIC production rates were also significantly higher in leaves decay, followed by branches and litter, respectively (Figure 1d, Table 1) DIC production rates were higher in the early $2 \mathrm{~h}$ of leaves breakdown (Figure 1d). In the branches decay, the higher DIC production rates were also observed in the first $2 \mathrm{~h}$ of experiment and, in litter decomposition, the highest rate of DIC production occurred only after $8 \mathrm{~h}$ (Figure 1d).

The kinetics model fitted the experimental results with high determination coefficients $\left(r^{2}=0.99-1.00\right)$ to oxygen accumulated consumption (Table 2). However, adjustments were partial in the decomposition of branches and litter (up to $7 \mathrm{~h}$ ), due to the increase of $\mathrm{O}_{2}$ consumption after this period, not adjusting to the model (Figure 1e). The accumulated oxygen consumption in the mineralization of leaves was significantly higher than branches and litter (Figure 1e, Table 1), in accordance with the higher value of the deoxygenation rate constant $\left(\mathrm{K}_{\mathrm{d}}\right)$ observed in leaves, followed by branches and litter, respectively (Table 2). Rates of oxygen consumption were higher in the decomposition of leaves at the beginning of the experiment (Figure 1f). Later (after $7 \mathrm{~h}$ ) an inversion occurred, with the decomposition of branches presenting the highest rates, followed by decomposition of litter and leaves, respectively (Figure 1f).
In opposition to the cumulative consumption of oxygen, the $\mathrm{O} / \mathrm{C}$ ratio in the decomposition of litter was significantly higher than in the decomposition of leaves and branches (Figure 1g, Table 1). No significant difference was detected between the O/C ratio for leaves and branches (Figure $1 \mathrm{~g}$, Table 1). The $\mathrm{O} / \mathrm{C}$ ratio in the decomposition of leaves and branches increased continuously, whereas the decomposition of litter showed an initial increase followed by a decrease and then increased again (Figure 1g).

The electrical conductivity was significantly higher in leaves than in branches and litter (Figure 1h; Table 1). The electrical conductivity increased for all resources throughout the experiment (Figure 1h).

\section{Discussion}

We observed a significant positive effect of detritus quality (DOC release) on DO consumption, on $\mathrm{DIC}$ formation, and on $\mathrm{O} / \mathrm{C}$ ratio in the early hours of decomposition, and these results support our first hypothesis. We also observed that the peak of labile compounds mineralization occurred in the first hour of decomposition of leaves and branches and in the eleventh hour of litter decomposition, supporting our second hypothesis of changes in detritus quality along decomposition. Our results highlight two important aspects of the conceptual development of reservoirs research. Firstly, our findings highlight the importance of short intervals measurements to understand the dynamics of decomposition in the leaching phase. Secondly, these results indicate that the oxygen depletion that occurs during the filling phase of reservoirs, reported in other studies (e.g. Ribeiro et al., 2005; Figueiredo and Bianchini Jr., 2008; Lee et al., 2012), can take place rapidly after the drowning of plant biomass, mainly by leaching from leaves and branches.

The difference in the amount of DOC released by detritus occurred as a result of different chemical composition (labile and refractory fractions) among resources, which is conferred by structural characteristics. Higher concentration of DOC observed from leaf detritus leaching is consistent with the higher protoplasmic content of this structure. The intermediate DOC concentrations from branches detritus agreed with its structural role, having a higher amount of fibers (lignin and cellulose) than leaves. The decaying organic matter that composes the litter has already lost protoplasmic content, resulting in lower concentrations of DOC. These results are in agreement with the large 

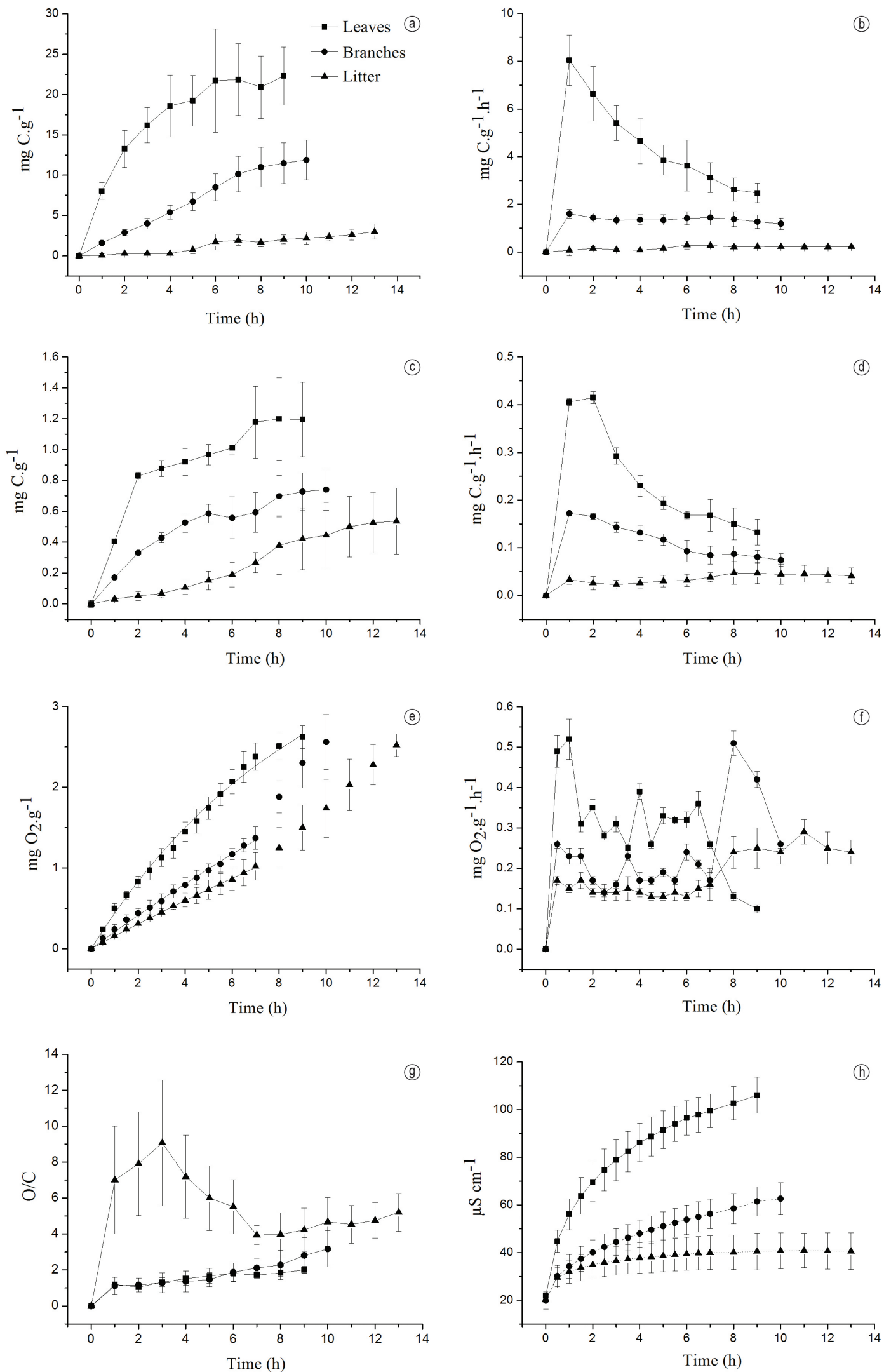

Figure 1. Temporal variation (a) and the hourly rates (b) of DOC release, temporal variation (c) and the hourly rates (d) of DIC production, kinetic fittings (e) and the hourly rates (f) of $\mathrm{O}_{2}$ consumption, temporal variation of stoichiometry $(\mathrm{O} / \mathrm{C}$ ratio) $(\mathrm{g})$ and electrical conductivity $(\mathrm{h})$ from aerobic mineralization of leaves, branches and litter. $[\mathrm{n}=3$, bars $=$ standard deviation]. 
Table 1. Values of significance (p) of ANCOVA test, degrees of freedom (DF) and residual (DF Res.) and values of deviance (F) for DOC, DOC rate, DIC, DIC rate, $\mathrm{O}_{2}$ consumption, $\mathrm{O}_{2}$ consumption rate, $\mathrm{O} / \mathrm{C}$ ratio and conductivity between detritus.

\begin{tabular}{|c|c|c|c|c|c|}
\hline \multicolumn{2}{|c|}{ ANCOVA } & \multirow{2}{*}{$\begin{array}{c}\text { DF } \\
1\end{array}$} & \multirow{2}{*}{$\frac{\text { DF Res. }}{60}$} & \multirow{2}{*}{$\frac{F}{138.0}$} & \multirow{2}{*}{$\frac{\mathbf{p}}{<0.01}$} \\
\hline DOC & leaves $\mathrm{x}$ branches & & & & \\
\hline & leaves $\mathrm{x}$ litter & 1 & 69 & 247.6 & $<0.01$ \\
\hline & branches $\mathrm{x}$ litter & 1 & 72 & 158.2 & $<0.01$ \\
\hline \multirow[t]{3}{*}{ DOC rate } & leaves $\mathrm{x}$ branches & 1 & 60 & 45.3 & $<0.01$ \\
\hline & leaves $\mathrm{x}$ litter & 1 & 69 & 105.3 & $<0.01$ \\
\hline & branches $\mathrm{x}$ litter & 1 & 72 & 236.6 & $<0.01$ \\
\hline \multirow[t]{3}{*}{ DIC } & leaves $\mathrm{x}$ branches & 1 & 60 & 84.0 & $<0.01$ \\
\hline & leaves $\mathrm{x}$ litter & 1 & 69 & 233.6 & $<0.01$ \\
\hline & branches $\mathrm{x}$ litter & 1 & 72 & 119.8 & $<0.01$ \\
\hline \multirow[t]{3}{*}{ DIC rate } & leaves $x$ branches & 1 & 60 & 22.3 & $<0.01$ \\
\hline & leaves $x$ litter & 1 & 69 & 78.6 & $<0.01$ \\
\hline & branches $\mathrm{x}$ litter & 1 & 72 & 72.3 & $<0.01$ \\
\hline \multirow{3}{*}{$\mathrm{O}_{2}$ consumption } & leaves $\mathrm{x}$ branches & 1 & 102 & 226.4 & $<0.01$ \\
\hline & leaves $\mathrm{x}$ litter & 1 & 111 & 325.1 & $<0.01$ \\
\hline & branches $\mathrm{x}$ litter & 1 & 114 & 53.4 & $<0.01$ \\
\hline \multirow[t]{3}{*}{$\mathrm{O}_{2}$ consumption rate } & leaves $\mathrm{x}$ branches & 1 & 102 & 75.7 & $<0.01$ \\
\hline & leaves $\mathrm{x}$ litter & 1 & 111 & 183.2 & $<0.01$ \\
\hline & branches $\mathrm{x}$ litter & 1 & 114 & 43.2 & $<0.01$ \\
\hline \multirow[t]{3}{*}{$\mathrm{O} / \mathrm{C}$ ratio } & leaves $\mathrm{x}$ branches & 1 & 60 & 6.6 & 0.012 \\
\hline & leaves $\mathrm{x}$ litter & 1 & 69 & 27.1 & $<0.01$ \\
\hline & branches $\mathrm{x}$ litter & 1 & 72 & 22.7 & $<0.01$ \\
\hline \multirow[t]{3}{*}{ Conductivity } & leaves $\mathrm{x}$ branches & 1 & 102 & 299.0 & $<0.01$ \\
\hline & leaves $\mathrm{x}$ litter & 1 & 111 & 335.7 & $<0.01$ \\
\hline & branches $\mathrm{x}$ litter & 1 & 114 & 73.2 & $<0.01$ \\
\hline
\end{tabular}

Table 2. Kinetics model parameterization from aerobic mineralization of leaves, branches and litter.

\begin{tabular}{lccccc}
\hline Resource & $\mathbf{O C}_{\max }\left(\mathbf{m g ~ g}^{-1}\right)$ & error & $\mathbf{k}_{\mathbf{d}}\left(\mathbf{h}^{-1}\right)$ & error & $\mathbf{r}^{\mathbf{2}}$ \\
\hline Leaves & 4.79 & 0.39 & 0.093 & 0.010 & 0.996 \\
Branches & 7.38 & 2.71 & 0.029 & 0.011 & 0.997 \\
Litter & 6.18 & 1.01 & 0.025 & 0.004 & 1.000 \\
\hline
\end{tabular}

proportion of dissolved organic matter in the green parts of vegetation and with the greater leaching of younger substrates (leaves and branches) as the older substrates (litter) have been previously leached (Bourbonniere and Creed, 2006; Allan and Castillo, 2007; Schindler and Gessner 2009; Ferreira et al., 2012).

In addition to carbon, various other components are leached. The leaching rate of a nutrient is influenced by the form it is incorporated into the organic matter (Brock, 1984). Some of them are loosely bound in plant material and have high solubility (e.g. $\mathrm{K}, \mathrm{Na}, \mathrm{Ca}$ and inorganic $\mathrm{P}$ ), becoming readily available to microorganisms without metabolic cost (Barbieri and Esteves, 1991; Schreeg et al., 2013). These elements contribute to the increase in electrical conductivity in the aquatic environment (Esteves, 2011). In this study, the greatest increase in conductivity was observed in the decomposition of leaves, indicating that this resource is the most critical for increasing the conductivity during reservoir formation. This result is in agreement with the concomitant higher DOC release observed in leaves decomposition.

Among terrestrial plant detritus, leaves are the most critical resource in terms of oxygen consumption due to the great amount of labile substances (Antonio et al., 2002; Bianchini Jr. and Cunha-Santino, 2011). In our study, the highest value of $\mathrm{k}_{\mathrm{d}}$ in the decomposition of leaves indicates that this resource was more intensely mineralized, showing the labile nature of its leachate. The maximum rates of DIC production and of DO consumption observed in the first hour of leaves decomposition indicated that the labile compounds were immediately released after the detritus incubation. More importantly, the small amount of DOC released from leaves in that moment indicated that the main components of DOC in the early decomposition are labile substances. Bianchini Jr. 
and Cunha-Santino (2011) also observed that the higher demands of oxygen derived from the oxidation of low concentrations of organic matter during the initial phases of terrestrial vegetation decomposition.

Branches and litter showed an initial peak $(0.5 \mathrm{~h})$ in the rates of oxygen consumption and, after a more stable period, a further increase (after $7 \mathrm{~h}$ ) in the rates of oxygen consumption was observed, suggesting that there was availability of labile substances in both times. After the decomposition of labile compounds from the leachate, changes in the chemical characteristics of the detritus along decomposition lead to a new availability of labile compounds derived from refractory substances (Peret and Bianchini Jr., 2004). In this context, we infer that the kinetic model of oxygen consumption did not fit the results of branches and litter after $7 \mathrm{~h}$ due to the enhancement of oxygen consumption in response to the availability of new labile compounds. In contrast to other studies (Antonio et al., 2002; Cunha-Santino et al., 2013), branches were significantly more critical in terms of oxygen consumption than litter. In our study, the results may be attributed to the greater amount of DOC released by branches in the leaching phase. Despite the lower oxygen consumption in branches decomposition in relation to leaves, we infer that branches may also generate a high oxygen demand in the reservoirs formation, whereas the total biomass of branches in forests is much greater than that of leaves (Delitti and Burger, 2000; Hart et al., 2003).

The OCmax values in this study were much lower than the observed in studies of mineralization of leaves (124.4 to $381.6 \mathrm{mg} \mathrm{g}^{-1} \mathrm{DW}$ ), branches (35.4 to $134.7 \mathrm{mg} \mathrm{g}^{-1} \mathrm{DW}$ ) and litter (88.1 to $\left.126.1 \mathrm{mg} \mathrm{g}^{-1} \mathrm{DW}\right)$ in greater experimental periods (60 days) (Antonio et al., 2002; Bianchini Jr. and Cunha-Santino, 2011; Cunha-Santino et al., 2013). The lowest values of OCmax in our study were attributed to smaller experimental period (9 to $13 \mathrm{~h}$ ), which included the decomposition of a small fraction of the waste, mainly comprised of labile compounds. Greater experimental periods include the decomposition of a larger fraction of the detritus, comprising the remaining refractory fractions and increasing the OCmax values.

The leachate is chemically heterogeneous, comprising labile and refractory fractions (Silva et al., 2011). Lower O/C ratios occur during mineralization of labile compounds from leachate, and higher $\mathrm{O} / \mathrm{C}$ ratios occur during mineralization of the remaining refractory compounds (Peret and
Bianchini Jr., 2004; Bianchini Jr. et al., 2010). The higher $\mathrm{O} / \mathrm{C}$ ratios observed in the beginning of litter decomposition indicated the presence of more refractory compounds in the leachate of litter in relation to leaves and branches. The subsequent decrease in $\mathrm{O} / \mathrm{C}$ ratios probably resulted from the new availability of labile compounds derived from refractory substances of litter (Peret and Bianchini Jr., 2004). In the decomposition of leaves and branches, increasing values in the $\mathrm{O} / \mathrm{C}$ ratio can be attributed to the mineralization of labile compounds leached, generating small O/C ratio in the beginning, being gradually replaced by more refractory compounds, increasing the $\mathrm{O} / \mathrm{C}$ values. More importantly, the values of the $\mathrm{O} / \mathrm{C}$ ratio did not differ significantly between leaves and branches, indicating a probable structural similarity (chemical composition) of these resources. Therefore, the significantly higher values observed in DIC formation and in $\mathrm{O}_{2}$ consumption in the decomposition of leaves was due to the higher amount of DOC released by this resource in relation to branches, and not by a difference between their chemical compositions. We infer that the stoichiometric ratio is an important predictor of structural differences between the detritus and of structural changes of each type of detritus along the decomposition.

In summary, the results from the experimental decomposition of drowned terrestrial vegetation indicate that: (i) measurements at short intervals are key to better understanding and detailing the decomposition in the leaching phase; (ii) resources are heterogeneous from the structural point of view, with the leaves presenting the largest amount of DOC, followed by branches and litter, respectively; (iii) leachate is also heterogeneous and the amount of labile fractions initially in the DOC determines the magnitude of the decomposition of leaves, branches and litter in the early stages of decomposition; (iv) leaves are the most critical resource in terms of oxygen consumption in the formation of reservoirs; (v) the stoichiometric ratio indicates the structural differences between the detritus and the structural changes in the detritus along decomposition. We propose that further studies should focus on assessing the contribution of different terrestrial plant species on the $\mathrm{C}$ cycling during the reservoirs formation.

\section{Acknowledgments}

The authors are grateful to Jorge Martins for laboratorial assistance and Sonia Nina for logistical support. This study was supported by the Program 
of Research and Technological Development of the Brazilian Electric Sector (Agreement: National Agency of Electric Energy (ANEEL), Furnas and UERJ; ANEEL proc. no.: 15.28305/10) and received support from CAPES (Coordenação de Aperfeiçoamento de Pessoal de Ensino Superior) by way of the fellowship provided to A. L. S. Fonseca.

\section{References}

ALLAN, JD. and CASTILLO, MM. 2007. Stream ecology: structure and function of running waters. Dordrecht: Springer. $436 \mathrm{p}$.

ALVES, LF., VIEIRA, SA., SCARANELLO, MA., CAMARGO, PB., SANTOS, FAM., JOLY, CA. and MARTINELLI, LA. 2010. Forest structure and live aboveground biomass variation along an elevational gradient of tropical Atlantic moist forest (Brazil). Forest Ecology and Management, vol. 260, no. 5, p. 679-691. http://dx.doi.org/10.1016/j. foreco.2010.05.023

ANTONIO, RM., BITAR, AL. and BIANCHINI JR., I. 2002. Consumo de oxigênio na mineralizaçáo de folhas, galhos, cascas e serapilheira. Acta Limnologica Brasiliensia, vol. 11, no. 2, p. 65-78.

BARBIERI, R. and ESTEVES, FA. 1991. The chemical composition of some aquatic macrophyte species and implications for the metabolism of a tropical lacustrine ecosystem - Lobo Reservoir, Sáo Paulo, Brazil. Hydrobiologia, vol. 213, no. 2, p. 133-140. http://dx.doi.org/10.1007/BF00014999

BIANCHINI JR., I. and CUNHA-SANTINO, MB. 2005. The decomposition of drowned biomass during filling of reservoirs. In SANTOS, MA. and ROSA, LP., org. Global warming and hydroelectric reservoirs. 1. ed. Rio de Janeiro: COPPE/UFRJ. p. 55-66.

BIANCHINI JR., I. and CUNHA-SANTINO, MB. 2008. As rotas de liberação do carbono dos detritos de macrófitas aquáticas. Oecologia Brasiliensis, vol. 12 , no. 1, p. 20-29. http://dx.doi.org/10.4257/ oeco.2008.1201.03

BIANCHINI JR., I. and CUNHA-SANTINO, MB. 2011. Model parameterization for aerobic decomposition of plant resources drowned during man-made lakes formation. Ecological Modelling, vol. 222, no. 7, p. 1263-1271. http://dx.doi. org/10.1016/j.ecolmodel.2011.01.019

BIANCHINI JR., I., PERET, AM. and CUNHASANTINO, MB. 2006, A mesocosm study of aerobic mineralization of seven aquatic macrophytes. Aquatic Botany, vol. 85, no. 2, p. 163-167. http://dx.doi. org/10.1016/j.aquabot.2006.03.001

BIANCHINI JR., I., SILVA, RH., CUNHA-SANTINO, MB. and PANHOTA, RS. 2010. Aerobic and anaerobic decomposition of Pistia stratiotes leachates from a tropical eutrophic reservoir (Barra Bonita, SP,
Brazil). Brazilian Journal of Biology, vol. 70, no. 3, p. 559-568. http://dx.doi.org/10.1590/S151969842010000300012

BOURBONNIERE, RA. and CREED, IF. 2006. Biodegradability of dissolved organic matter extracted from a chronosequence of forest-floor materials. Journal of Plant Nutrition and Soil Science, vol. 169, no. 1, p. 101-107. http://dx.doi.org/10.1002/ jpln.200521721

BREZONIK, PL. 1994. Chemical kinetics and process dynamics in aquatic systems. Boca Raton: Lewis. $754 \mathrm{p}$.

BROCK, TCM. 1984. Aspects of the decomposition of Nymphoides peltata (Gmel.) O. Kuntze (Menyanthaceae). Aquatic Botany, vol. 19, no. 1-2, p. 131-156. http://dx.doi.org/10.1016/03043770(84)90013-5

CUNHA-SANTINO, MB. and BIANCHINI JR., I. 2002. Estequiometria da decomposição aeróbia de galhos, cascas, serapilheira e folhas. In ESPÍNDOLA, ELG., MAUAD, FF., SCHALCH, W., ROCHA, O., FELICIDADE, N. and RIETZLER, AC., eds. Recursos hidroeneréticos: usos, impactos e planejamento integrado. São Carlos: RiMa. 346 p.

CUNHA-SANTINO, MB. and BIANCHINI JR., I. 2006. Modelos matemáticos aplicados aos estudos de decomposição de macrófitas aquáticas. Oecologia Brasiliensis, vol. 10, no. 2, p. 154-164. http://dx.doi. org/10.4257/oeco.2006.1002.03

CUNHA-SANTINO, MB., BITAR, AL. and BIANCHINI JR., I. 2013. Chemical constraints on new man-made lakes. Environmental Monitoring and Assessment, vol. 185, no. 12, p. 10177-10190. PMid:23877574. http://dx.doi.org/10.1007/ s10661-013-3322-0

DELITTI, WBC. and BURGER, DM. 2000. Carbon and mineral nutrient pools in a gallery forest at Mogi Guaçu River, Southeast Brazil. Annals of Forest Science, vol. 57, no. 1, p. 39-47. http://dx.doi. org/10.1051/forest:2000109

ESTEVES, FA. 2011. Fundamentos de limnologia. 3th ed. Rio de Janeiro: Interciência. 826 p.

FERREIRA, V., ENCALADA, AC. and GRAÇA, MAS. 2012. Effects of litter diversity on decomposition and biological colonization of submerged litter in temperate and tropical streams. Freshwater Science, vol. 31, no. 3, p. 945-962. http://dx.doi. org/10.1899/11-062.1

FIGUEIREDO, DM. and BIANCHINI JR., I. 2008. Limnological patterns of the filling and stabilization phases in the Manso multiple-use reservoir (MT). Acta Limnologica Brasiliensia, vol. 20, no. 4, p. 277-290.

FITZHUGH, TW. and RICHTER, BD. 2004, Quenching urban thirst: growing cities and their impacts on freshwater ecosystems. BioScience, vol. 54, 
no. 8, p. 741-754. http://dx.doi.org/10.1641/00063568(2004)054[0741:QUTGCA]2.0.CO;2

FONSECA, ALS., BIANCHINI JR., I., PIMENTA, CMM., SOARES, CBP. and MANGIAVACCHI, N. 2013. The flow velocity as driving force for decomposition of leaves and twigs. Hydrobiologia, vol. 703, no. 1, p. 59-67. http://dx.doi.org/10.1007/ s10750-012-1342-3

FRANÇA, JS., GREGÓRIO, RS., D’ARC DE PAULA, J., GONÇALVES JR., JF., FERREIRA, FA. and CALLISTO, M. 2009. Composition and dynamics of allochthonous organic matter inputs and benthic stock in a Brazilian stream. Marine and Freshwater Research, vol. 60, no. 10, p. 990-998. http://dx.doi. org/10.1071/MF08247

HART, PBS., CLINTON, PW., ALLEN, RB., NORDMEYER, AH. and EVANS, G. 2003. Biomass and macro-nutrients (above- and belowground) in a New Zealand beech (Nothofagus) forest ecosystem: implications for carbon storage and sustainable forest management. Forest Ecology and Management, vol. 174, no. 1-3, p. 281-294. http:// dx.doi.org/10.1016/S0378-1127(02)00039-7

IBRAHIMA, A., JOFFRE, R. and GILLON, D. 1995. Changes in litter during the initial leaching phase: an experiment on the leaf litter of Mediterranean species. Soil Biology and Biochemistry, vol. 27, no. 7, p. 931-939. http://dx.doi.org/10.1016/00380717(95)00006-Z

LEE, N., YEE, LT. and GRINANG, J. 2012. Physicochemical characteristics in the filling phase of Bakun hydroelectric reservoir, Sarawak, Malaysia. International Journal of Applied Science and Technology, vol. 2, no. 6, p. 92-101.

PAIVA, MP. 1988. Deforestation of large reservoirs basins. Regulated Rivers: Research and Management, vol. 2, no. 1, p. 57-60. http://dx.doi.org/10.1002/ rrr.3450020106

PERET, A. and BIANCHINI JR., I. 2004. Stoichiometry of aerobic mineralization $(\mathrm{O} / \mathrm{C})$ of aquatic macrophytes leachate from a tropical lagoon (São Paulo - Brazil). Hydrobiologia, vol. 528, no. 1-3, p. 167-178. http://dx.doi.org/10.1007/s10750004-2340-x
PETTIT, N., DAVIES, T., FELLMAN, J., GRIERSON, P., WARFE, D. and DAVIES, P. 2012. Leaf litter chemistry, decomposition and assimilation by macroinvertebrates in two tropical streams. Hydrobiologia, vol. 680, no. 1, p. 63-77. http:// dx.doi.org/10.1007/s10750-011-0903-1

PETTS, GE. 1984. Impounded rivers: perspectives for ecological management. Chichester: John Wiley. 326 p.

PRESS, WH., TEUKOLSKY, SA., VETTERLING, WT. and FLANNEY, BP. 2007. Numerical recipes: the art of scientific computing. New York: Cambridge University Press. 1235 p.

RIBEIRO, LHL., BRANDIMARTE AL. and KISHI, RT. 2005. Formation of the Salto Caxias Reservoir (PR): an approach on the eutrophication process. Acta Limnologica Brasiliensia, vol. 17, no. 2, p. 155-165.

SCHINDLER, MH. and GESSNER, MO. 2009. Functional leaf traits and biodiversity effects on litter decomposition in a stream. Ecology, vol. 90, no. 6, p. 1641-1649. PMid:19569378. http://dx.doi. org/10.1890/08-1597.1

SCHREEG, LA., MACK, MC. and TURNER, BL. 2013. Nutrient-specific solubility patterns of leaf litter across 41 lowland tropical woody species. Ecology, vol. 94, no. 1, p. 94-105. PMid:23600244. http://dx.doi.org/10.1890/11-1958.1

SILVA, RH., PANHOTA, RS. and BIANCHINI JR., I. 2011. Aerobic and anaerobic mineralization of Salvinia molesta and Myriophyllum aquaticum leachates from a tropical reservoir (Brazil). Acta Limnologica Brasiliensia, vol. 23, no. 2, p. 109-118. http://dx.doi. org/10.1590/S2179-975X2011000200001

TANK, JL., ROSI-MARSHALL, EJ., GRIFFITHS, NA., ENTREKIN SA. and Stephen, ML. 2010. A review of allochthonous organic matter dynamics and metabolism. Journal of the North American Benthological Society, vol. 29, no. 1, p. 118-146. http://dx.doi.org/10.1899/08-170.1

TUNDISI, JG. 1999. Reservatórios como sistemas complexos: teoria, aplicaçóes e perspectivas para usos múltiplos. In HENRY, R., ed. Ecologia de reservatórios: estrutura, função e aspectos sociais. Botucatu: FUNDIBIO/FAPESP. 800 p.

Received: 20 August 2013 Accepted: 27 May 2014 